\title{
Decentralised combined heat and power in the German Ruhr Valley; assessment of factors blocking uptake and integration
}

Birte Viétor ${ }^{1}$, Thomas Hoppe ${ }^{2^{*}}$ and Joy Clancy ${ }^{2}$

\begin{abstract}
Background: In Germany, the energy system is undergoing reorganisation from a centralised system based on fossil fuels and nuclear power to a sustainable system based on decentralised production and consumption of energy, the so-called Energiewende. Recently, there has been more attention to improving energy efficiency in those regions where conventional energy production activities and energy-intensive industries are located, such as the Ruhr area. Although the potential for decentralised combined heat and power (CHP) units is high in this region, local action plans show only modest developments for this technology. In this paper, we address this issue by answering the following research question: Which factors block the uptake and integration of decentralised CHP in the German Ruhr area's energy system?

Methods: The multilevel perspective (MLP) was used to analyse the state of system innovation in relation to the uptake and integration of decentralised CHP technology. Prior to the MLP analysis, a stakeholders' analysis was conducted to identify stakeholders' views, positions and experienced barriers regarding the uptake and integration of decentralised CHP technology. Data collection included review of text documents and conducting 11 interviews.

Results: Due to many regime barriers blocking niche development, the uptake of decentralised CHP technology is limited. Identified barriers relate to lack of market services and mismatches with user preferences, (sectoral) policies and industrial interests.

Conclusions: Observed barriers relate to (i) lack of market services such as financial means for making investments; (ii) user awareness such as unawareness and information deficit regarding the benefits of decentralised CHP to potential users, (iii) the presence of centralised district heating systems, (iv) policy issues such as lack of sufficient policies supporting diffusion of decentralised CHP units, legal stipulations from social housing policies that prevent housing cooperatives from becoming energy producers and district heating systems owned by public and private owners (via concessions contracts); ( $v$ ) sector issues such as lack of skilled service-providing companies; and (vi) industrial interested such as the vested interests of the coal and gas industry. Moreover, many of the mentioned barriers seem interrelated, especially those concerning policy and finance available for making upfront investments.
\end{abstract}

Keywords: Energy transition; Decentralised CHP; Energy efficiency; Multilevel perspective

\footnotetext{
* Correspondence: t.hoppe@utwente.n

${ }^{2}$ Department of Governance and Technology for Sustainability (CSTM),

Institute for Governance and Innovation Studies (IGS), University of Twente,

Drienerlolaan 5, 7522, NB Enschede, The Netherlands

Full list of author information is available at the end of the article
} 


\section{Background}

Following the 2011 Fukushima nuclear disaster in Japan, the political decision was made in Germany to phase out nuclear power production by 2022 and to initiate a countrywide energy transition, the Energiewende. In short, it stands for a transition of the entire energy system in Germany which 'involves replacing, or supplementing, established technologies with new ones' [1] and thereby performing the 'inevitable shift away from cheap, centralized, largely fossil-based energy systems towards decentralised energy systems to a large extent based on renewable energy sources' [2] (translation by the authors). Next to increasing the share of renewable energy within the total primary energy supply to $50 \%$ by 2050 , the program mentions the urgent need for action particularly in those regions where conventional energy production activities and energy-intensive industries are located. In these areas, there is large potential for using energy more efficiently. One way to foster energy efficiency is by supporting adoption of decentralised combined heat and power (CHP) units. The Federal Government of Germany strives to raise the share of combined heat and power generation to $25 \%$ by 2020 [3]. Since the opportunities for centralised district heating systems have already been utilised to a large extent, and are difficult to change over the short term for infrastructural and contractual reasons, raising the share of CHP would mean increasing the share of decentralised CHP units.

The Ruhr Valley in the Federal State of North Rhine-Westphalia (NRW) is a very striking example of a region for increasing energy efficiency levels since this is where many conventional energy production activities and energy-intensive industries are located. It is home to the majority of the coal power plants in Germany, and around one third of all German GHG emissions (313 million $\mathrm{CO}_{2}$ eq in 2010) are registered in this area. Furthermore, almost $30 \%$ of the national electricity demand is produced in this area (180 million kWh in 2011 in NRW; 608 million kWh in 2011 in Germany [4]), and around 25\% of German final energy is used here. Moreover, $40 \%$ of the German energy demand for industrial processes originates in the Ruhr Valley [5].

The report 'Deutschlands Energiewende. Ein Gemeinschaftswerk für die Zukunft' ('Germany's energy transition. Collaborative work for the future'; translation by the authors) that was published by the Ethical Commission on behalf of the Federal Government in May 2011 underlines the important role decentralised governments have in implementing Energiewende policies. For instance, the report points out that it is the municipalities, rather than the central or state government, that have the planning authority when it comes to locating sustainable energy production utilities. Furthermore, municipalities are responsible for public buildings and public transport; via their municipal energy suppliers and housing societies, they are delivering electricity and heat [6,7], and potentially, they can have policies in place to influence energy consumption by local stakeholders. Moreover, it is at the local level that environmental matters (including energy transition) manifest and citizens engage with government [8]. Hence, cities and regions can become powerful promoters of sustainable transitions [9]. Against this background, it is reasonable to discuss the energy transition approaches from a situational perspective as we deem the situational context and hence specific regional conditions, of great importance to strategies to effectuate energy transitions in cities and regions. In particular, situational conditions might favour adoption and rollout of one particular energy transition pathway, whereas it might disfavour alternatives pathways.

It is for these reasons that we explore the potential uptake and integration of decentralised CHP in the Ruhr Valley. Although the Energiewende is widely known to support diffusion of wind and solar systems for power production; in particular, it focuses on electricity generation from renewable sources; it also highlights the need for action towards using energy more efficiently in those regions where conventional energy production activities and energy-intensive industries are located, notably the Ruhr Valley. Given its very nature, the industrial, highly populated urban region of the Ruhr Valley offers high potential for further take up, integration and upscaling of decentralised CHP. In NRW, the share of CHP total electricity production, however, amounted to only $10 \%$ $[10] .^{a}$ Hence, it is far removed from the national target of $25 \%$.

Analysis of the local climate change protection action plans addressing the uptake and integration of decentralised $\mathrm{CHP}$ units provides an overview on the importance that is given to the uptake of this technology by nine Ruhr Valley cities (see Table 1).

Eight out of the nine cities have formulated measures that aim at increasing the share of heat and power produced in decentralised CHP units. ${ }^{\mathrm{b}}$ The actions planned by these eight municipalities differ in various ways. Whereas some municipalities mention in their local action plans that decentralised CHP should be used in municipal buildings, others target local stakeholders, like households and commercial firms. Different policy actions are mentioned such as constructing apartment block-heating installations, integration of decentralised CHP units in urban development planning and establishing contracts with private home owners for the provision of heat. In some municipalities, decentralised CHP is seen as a means to feed in decentralised-produced heat into the existing district heating grids. In this way, decentralised $\mathrm{CHP}$ can be seen as a means to 'extend' existing (district) 
Table 1 Overview is policy action plans Ruhr city governments have prepared regarding CHP

\begin{tabular}{|c|c|c|c|}
\hline City & $\begin{array}{l}\text { Year of origin of policy } \\
\text { action plan }\end{array}$ & Inhabitants & Actions regarding decentralised $\mathrm{CHP}$ \\
\hline Bochum & 2009 & 373,000 & $\begin{array}{l}\text { Feasibility study: integration of small CHP (buildings) in the regional supply concept } \\
\text { ('virtual power plant'). }\end{array}$ \\
\hline Bottrop & 2011 & 116,000 & $\begin{array}{l}\text { Local heating grid Kirchhellen: construction of a CHP plant of 15,000 kW with local } \\
\text { heating grid on the basis of renewable energies (biogas, wood). }\end{array}$ \\
\hline \multirow[t]{2}{*}{ Dortmund } & \multirow[t]{2}{*}{2011} & \multirow[t]{2}{*}{580,000} & Potential study of utilising CHP units in private households and the commercial sector \\
\hline & & & Block-heating station-'Push' in municipal properties. \\
\hline Duisburg & 2009 & 488,000 & None. \\
\hline Essen & 2009 & 573,000 & Integration of urban development contracts into town plans to regulate use of $\mathrm{CHP}$. \\
\hline \multirow[t]{4}{*}{ Gelsenkirchen } & \multirow[t]{4}{*}{2011} & \multirow[t]{4}{*}{256,000} & Block-heating station-'Push' in municipal properties. \\
\hline & & & Pilot project: 'Extension of $\mathrm{CHP}^{\prime}$. \\
\hline & & & Local heating grid in interconnection (potential analysis for block heating stations). \\
\hline & & & Combination of geothermal energy and micro-CHP. \\
\hline \multirow[t]{2}{*}{ Oberhausen } & \multirow[t]{2}{*}{2012} & \multirow[t]{2}{*}{212,000} & Heat supply in the form of heat contracting for private house owners. \\
\hline & & & Decentralised CHP for the local heating grid in Barmingholten. \\
\hline Recklinghausen & 2012 & 118,000 & Extension of (renewable energy) CHP in the city area. \\
\hline Witten & 2013 & 98,000 & 'Push' for combined heat and power. \\
\hline
\end{tabular}

heating grids. Not surprisingly, multiple Ruhr Valley local authorities deploy 'extension of CHP' actions in their respective programs due to the presence of centralised district heating grids. Studies regarding the technical and economic potential or feasibility of decentralised CHP have been prepared in four municipalities, and plans for constructing decentralised CHP units are mentioned by at least four (other) municipalities. The ways the nine city governments address the uptake and integration of decentralised CHP shows little coherence: between the nine municipal plans, there is little alignment in the formulation of goals and policy actions. In summary, the policy actions to spur the uptake and integration of decentralised CHP by the nine Ruhr Valley municipalities give the impression that uptake of decentralised CHP is at a rather early stage.

These findings stimulated us to find out why the uptake and integration of decentralised CHP is currently not at a more developed stage. A priori, we would expect that there would be a large-scale uptake and integration of CHP in the Ruhr Valley, but we do not see it in reality. Therefore, we aim to identify the factors that might explain why the potential for decentralised CHP is not being realised. The main research question of this paper is: Which factors block the uptake and integration of decentralised CHP in the German Ruhr area's energy system?

In order to answer the question, we use stakeholders' and systemic analytical perspectives for sustainable transitions. In line with Truffer and Coenen [9], we view sustainability transitions as political projects where stakeholder interrelationships play a crucial role in the transformation process. Therefore, we conduct a stakeholder analysis to identify relevant stakeholders' roles, positions, interrelationships, views and experienced barriers concerning the uptake and integration of decentralised CHP. Next, we analyse the systemic status quo regarding the uptake and integration of decentralised CHP into the energy system of the Ruhr Valley by using the multilevel perspective (MLP) framework for transitional change $[11,12]$.

\section{Background: the Ruhr Valley region context}

The Ruhr Valley is one of the biggest urban agglomerations in Europe with 5.2 million inhabitants. The region can be divided into 11 urban districts (Kreisfreie Städte; translation by authors) (Duisburg, Mülheim a. d. Ruhr, Oberhausen, Essen, Bottrop, Gelsenkirchen, Herne, Bochum, Dortmund, Hagen und Hamm) and four counties (Kreise) (Wesel, Unna, Recklinghausen und Ennepe-Ruhr). These in turn are composed of 43 independent cities and municipalities within the county. Figure 1 presents the siting of the region in Germany and the siting of administrative divisions within the Ruhr Valley [13].

The coal deposit of the Ruhr area provided the natural precondition for the development of the biggest coal and steel industry in Europe. Thus, historically, the Ruhr area was the hotspot for steel and chemistry industries economic sectors that are strongly linked to greenhouse gas emissions. During 150 years of industrialization, the region underwent strong spatial changes as settlements expanded and economic activity accelerated. Industrial and socio-economic institutions were essentially designed 

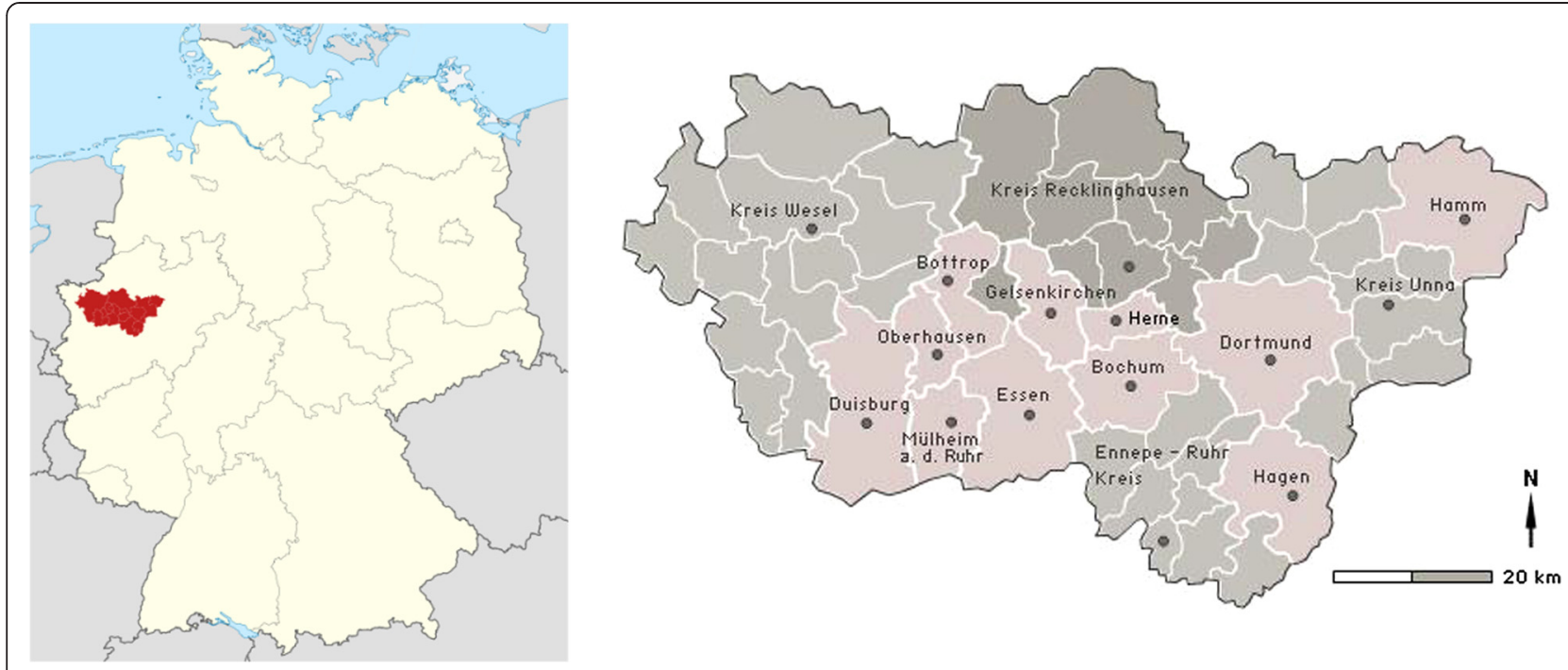

Figure 1 Siting of the Ruhr Valley region in Germany, and the Ruhr Valley's administrative divisions.

to serve the mining industry. While in the second half of the 19th century 280 coal mines were active in the region, this number diminished dramatically. In 2009, only four mines were left [14]. Nowadays, more than $70 \%$ of the population in the area is employed in the tertiary sector. This impressive development from an industrial to a knowledge society could not solve all problems that are linked to the 1950s crisis in the coal industry (e.g. high unemployment, financial debts) [15]. Some cities in the Ruhr area are nowadays among those in Germany with the highest unemployment rates (e.g. Duisburg, Dortmund). The unemployment rate contributes to the weak financial situation of the municipalities ${ }^{\mathrm{c}}$ which limits the scope for action.

\section{Background: decentralised CHP technology}

Low efficiency during the electricity generation processes results in energy being lost in the form of waste heat [16]. Collecting waste heat for reuse combined with electricity generation is a way to use primary energy more efficiently [17]. It is the combination of the electrical generation and heat production process that forms the basis of the CHP concept [18]. The overall efficiency can reach up to $90 \%$, whereas single-electricity generation only reaches efficiency levels of $30 \%$ to $60 \%$ [19]. Waste heat from the exhaust gases, or used steam, is recovered for instance to produce hot water for the use in district heating schemes (in large-scale CHP systems) or to heat spaces in buildings (using smaller decentralised CHP plants; [16]). Three categories for use of CHP have been defined by the German Federal Ministry of the Environment, Nature Protection and Nuclear Safety, one of them being decentralised CHP. The latter is typically used to supply heat and power for consumption in residential or commercial buildings [19].
In this paper, 'decentralised CHP' relates to $\mathrm{CHP}$ units used at the district level, street level or at the level of (multistorey) housing complexes. ${ }^{\mathrm{d}}$

Decentralised CHP offers considerable benefits as compared to conventional ways of heat and power production. First, it offers improved energy efficiency and preserves non-renewable energy reserves. Second, due to more efficient conversion of primary energy, reductions in ground-level particle and gas emissions and pollution can be realised, hence improving urban air quality [16]. Third, both fossil and renewable sources can be used in decentralised CHP plants; hence, technology can make an important contribution to reducing greenhouse gas emissions and the primary fossil fuel energy consumption in the future energy system [19].

\section{Background: decentralised CHP technology uptake in the Ruhr Valley energy system}

The integration of decentralised CHP into the German energy system forms an important cornerstone of the energy policy of the Federal Government of Germany. The Integrated Energy and Climate Protection Program (Integriertes Energie- und Klimaschutzprogramm) (2007) of the Federal Government of Germany includes the political target to raise the share of combined heat and power generation in Germany from the current level of about $13 \%$ to $25 \%$ by 2020 [3]. The important role CHP plays in the framework of the energy system transition was affirmed in a renewal of the respective law (Act on $\mathrm{CHP}$ ) and the creation of different funding policies (e.g. the Act on Renewable Energies). Since 2003, power and heat generation via CHP has increased by $20 \%$ and $8 \%$, respectively. In 2005, 18.2 TWh power was produced by $\mathrm{CHP}$ in NRW. Related to the entire power production 
in NRW (ca. $180 \mathrm{TWh} /$ year), the share of CHP amounted to only $10 \%[10]$.

In January 2013, the Federal State NRW adopted the first Climate Protection Act in Germany which contains legally binding climate protection objectives. The act aims at contributing to the achievement of the national climate change mitigation goals and acknowledges the potential that decentralised CHP has in helping reach these objectives. It further acknowledges the significant responsibility the region has in this respect, notably when compared to other German States. According to the Climate Protection Act, by 2020, GHG emissions are to be reduced by $25 \%$ relative to the 1990 level. By 2050, a reduction of $80 \%$ relative to the 1990 level is targeted. NRW also adopted the national CHP objective based on which the state government developed a program, the 'CHP Impulse Program', to increase the share of decentralised CHP in the area. The CHP Impulse Program, together with the national political conditions, makes the current political framework conditions seem supportive towards the integration of decentralised CHP into the energy system in NRW.

Recent studies on the potential of CHP in NRW (May 2011) and on district heating in the Ruhr area (May 2013) have stressed the significant potential for this technology in meeting policy goals. Both studies argue that it is economically viable to extend the district heating system, in particular to supply heat to more residential areas in the Ruhr Valley. However, the large-scale, centralised CHP plants that supply heat to the district heating grid are emphasised. At the same time, the studies mention some barriers that could have strong impacts on the operating efficiency of the district heating system. Namely, due to improvements in energy efficiency and insulation of buildings, it is predicted that there will be a decrease in demand for heat and electricity. Furthermore, demographic changes will have an impact on the number of customers demanding heat and electricity. At the same time, many coal power plants are expected to close down in the near future, because the profit margins are decreasing rapidly. Consequently, less heat will be generated and supplied to the grid. Interestingly, these barriers do not seem to have a significant impact on the formulation of recommendations for the future energy system.

The study 'Investigation of the potential of CHP in Northrhine-Westphalia' (in German: Potenzialerhebung von Kraft-Wärme-Kopplung in Nordrhein-Westfalen; translation by the authors) [20] states that an increase in the number of decentralised CHP plants will lead to decreased connection rates to the district heating grid which in turn will have a negative impact on the cost effectiveness of the latter. Although this sounds logical, it did not lead to any critical reflection by policy makers on how to overcome this potential conflict between centralised and decentralised supply of energy.
The study 'Perspectives of district heating in the Ruhr Area until 2050' (in German: Perspektiven der Fernwärme im Ruhrgebiet bis 2050; translation by the authors) [21] mentions briefly that there is a need for more flexibility and more heat sources to be able to maintain the economic viability of the district heating network. Responding to this point is very important as decentralised CHP units could theoretically ensure this flexibility and at the same time provide more heat sources.

In summary, there are five reasons why the potential for large-scale adoption of decentralised CHP in the Ruhr Valley should be considered worthwhile exploring. First, the two studies mentioned above underline the high potential regarding the further integration of CHP into the energy system as well as connecting to the existing district heating grid $[21,22]$. Second, the highgeographical proximity of cities in the Ruhr Valley combined with the high-population density in the area offer good preconditions for the efficient use of CHP both centralised and decentralised. Third, the decentralisation of energy production and consumption is a stated political objective (in the Energiewende program) and as such could provide a window of opportunity for policymaking to support decentralised CHP uptake and integration in the future energy system. Moreover, promoting energy efficiency is viewed as an urgent priority vis-à-vis the future of energy transition in Germany. Although supply of heat and power from cogeneration and energy efficiency in buildings have taken a backseat in the German energy transition agenda, these sectors have recently been identified by researchers as having significant potential [22]. Fourth, increased uptake of decentralised CHP allows for greater flexibility in responding to fluctuations in energy demand and supply. Fifth, decentralised CHP also allows for local use of renewable energy sources. For this reason, CHP can play an important role in the envisaged energy system transition in Germany and contribute to attaining climate change policy goals. In conclusion, decentralised CHP could potentially offer substantial benefits to energy producers, end users, policymakers and governmental actors.

\section{Theoretical framework: using the multilevel perspective to analyse regional energy transitions}

The challenge for the uptake and integration can be viewed as fostering a socio-technical and sustainable transition. A socio-technical transition is a set of processes that leads to a fundamental shift in socio-technical systems (e.g. $[23,24])$. A socio-technical system (such as the energy system) consists of '(networks of) actors (individuals, firms, and other organisations, collective actors) and institutions (societal and technical norms, regulations, standards of good practice), as well as material artefacts and knowledge. The different elements of the system 
interact, and together they provide specific services for society' [25]. The systems concept highlights the fact that a broad variety of elements is tightly interrelated and depends on each other [26].

Sustainability transitions, for instance those intended to attain the status of a low-carbon society, are also considered by researchers to be socio-technical transitions. Energy transitions, for example the Energiewende, can also be viewed as sustainability transitions. These are longterm, multidimensional and fundamental transformation processes through which established socio-technical systems shift to more sustainable modes of production and consumption. A key feature of sustainability transitions is that guidance and governance often play a significant role in the transition [27], when decisive interventions from state and non-state actors are needed to overcome the inertia and lock-in typically found in the prevailing sociotechnical systems $[26,28,29]$.

\section{Multilevel perspective on system innovation and transitional change}

Currently, the theoretical framework most used to understand and systematically analyse socio-technical transitions, in particular the energy transition (e.g. [30]), is the MLP $[11,12]$. The framework has been developed based on findings from evolutionary theory and systems analysis. According to Geels 'the stability of established socio-technical configurations results from the linkages between heterogeneous elements' [12], p. 1259. For MLP, these are linkages between three conceptual levels: macro, meso and micro.

On the macro level 'landscape events' occur. Landscape is associated with the material context of society. It is made up of various macro factors such as oil prices, interstate geopolitical relationships and forthcoming events (like treaties and wars), political and governmental coalitions, cultural values and major environmental problems. The socio-technical landscape forms the external context for action of, and interaction between, actors.

The meso level is referred to as the 'socio-technical regime'. These regimes encompass social and institutional rules that enable and constrain activities between actors [12]. These rules are related to several institutionalised factors, such as markets, user preferences, (sectoral) policies, industries, science, culture and technology. As a rule of thumb, socio-technical regimes only change incrementally and contain defence mechanisms to fend off attempts to replace them with alternatives, typically radical innovations developed at the micro level in 'socio-technical niches'.

The micro level is referred to as the analytical level in which 'socio-technical niches' develop. The niche is one of the central concepts in transition research. Niches form protective spaces in which radical innovation can develop, while being protected from regime defence mechanisms. An important question regarding the role of the niche is upscaling (e.g. addressing the question how to increase the take up and integration of the niche within society). Smith and Raven [31] differentiate three functions for niche protection: shielding, nurturing and empowering. Shielding refers to processes that hold at bay selection procedures from mainstream selection environments. Nurturing refers to processes such as learning, networking and expectation formation. Finally, empowering refers to the process that makes niche innovations competitive within unchained selection environments ('fit-and-conform') and processes that restructure mainstream selection environments in ways favourable to the niche ('stretch-and-transform'). Political, administrative, managerial and academic interest in how to encourage (sustainable) transitional change have led to the development of managerial transitional change frameworks, notably the Strategic Niche Management (SNM) [32,33] and Transition Management (e.g. [34,35]).

The interlinked character of the macro, meso and micro levels means that regimes are embedded within landscapes and niches within regimes. Innovations (and hence attempts to bring about transitional change) take off in niches in the context of existing regimes with their specific problems, rules and capabilities. Thus, in a transition process, interactions between dynamics exist between the three levels.

Theoretically, the systemic dynamics that result in transitional change follow a typical pattern. Landscape events (like the 2011 Fukushima nuclear disaster) create pressure on socio-technical regimes which result in problems that regimes cannot solve from within. Solving these problems via incremental regime optimization will not suffice to solve these problems and creates opportunities for alternative radical innovations with the potential to overthrow the current regime. This provides opportunities for new innovations that develop in niches and are supported by social networks (often including 'regime outsiders') that are active in niche formation activities. After iterative sets of niche experiments (e.g. by organising demonstration projects), innovations mature and have the potential to gain a foothold in the existing socio-technical regime. If successful, it can eventually replace the existing regime and hence the socio-technical system as such [36]. When replacement of an existing regime by a novel regime takes place, one can speak of system innovation. When this concerns a radical innovation, one can speak of transitional change. Breakthroughs of radical innovations consequently depend on interactive systemic processes within and between the macro, meso and micro levels (i.e. between landscape events, the sociotechnical regime and niches). In general, transitions are context dependent [12]. 
Although often used in academic studies of transitions, MLP and the related analytical frameworks that suggest 'management of transitions' (e.g. SNM, TM) have been criticised for failing to address context-related (regional and local) factors that influence the way in which innovations develop and transitions manifest (see e.g. [26,37,38]), notably addressing agency [39-41], politics and power [42-44]; the role of user groups in consumptive action $[37,45]$; the role of civil society in transitions [46,47]; policy $[48,49]$; and geographic-bound factors such as comparative institutional, socio-economic or infrastructural advantages that differ substantially from one geographic administrative jurisdiction to another [50]. When analysing energy transitions at a regional scale, identifying these factors is important because one needs to first understand the context, culture and historical pathways that explain the establishments of key institutions, interstakeholder power relations and comparative institutional (dis-)advantages. Based on this perception, the next step is then to understand the functioning of the socio-technical systems, before one attempts to plan and 'manage' transitional change. Based on this criticism, Geels recently [51] furthered the conceptualization of energy transitions by incorporating agency, power and politics. In relation to attaining low-carbon societies, he [52] states that there should be more academic attention to resistance by incumbent regime actors to fundamental change than continuing to overemphasise the potential of a great many 'green' innovations. Regarding future research agendas, this should be understood as shifting away from studying niche development to studying regime power and politics as defensive mechanisms to prevent radical change from happening. Hence, the unit of analysis should be the regime, not the niche. In this paper, we adopt Geels' view, although our initial focus is on a particular niche (decentralised CHP). However, the main part of our analysis addresses regime forces (see the 'Methods' section). ${ }^{\mathrm{e}}$

Furthermore, the paper contributes to the academic literature on the energy transition (strategies towards attaining low-carbon goals) in cities (e.g. [53-55]; and the thematic issue of which this paper is part [56]).

\section{Methods}

This paper presents the case study of the Ruhr Valley, which will be analysed in two ways, in which the results of the first analysis will be used as the input for the second analysis. First, a stakeholders' analysis will be conducted to identify key stakeholders, their positions in the regional energy system and barriers they experience in relation to the uptake and integration of decentralised CHP units. Second, a systemic analysis will be conducted using the MLP framework. Results from the stakeholders' analysis (notably identification of regime barriers) will be used as input for the analysis with MLP.

\section{Case selection}

The Ruhr Valley was selected for its urban and industrial regional character. Theoretically speaking, these characteristics would be expected to benefit the take up of energy efficiency technological pathways, in particular decentralised CHP. This makes our case different to other areas in Germany which have adopted renewable energy technologies on a large scale (in particular wind and solar energy) because they are more rural and hence spatially more suited to spur production of green electricity. Thus, case selection follows the criterion of the regional socioeconomic and spatial character. Selecting the Ruhr Valley as a regional case study should be seen as selecting an extreme case $\mathrm{f}^{\mathrm{f}}$ [57] for Germany as no other region compares readily to the Ruhr area. So, hypothetically, the highly industrial and urban character of the region, with potential for use of residual heat and high local demand for heat and power, should favour uptake and integration of decentralised CHP. As this study presents a (single) case study, external validity (and hence representativeness) is low. Nonetheless, potentially regions that also feature the previously mentioned characteristics can readily be compared with the Ruhr area. However, this is not the objective of this paper which only studies the one region.

\section{Stakeholders' analysis}

A stakeholder analysis is conducted to generate knowledge about the stakeholders involved with decentralised CHP 'so as to understand their behaviour, intentions, interrelations and interests; and for assessing the influence and resources they bring to bear on decision-making or the implementation process' [58], p. 338. The stakeholder analysis consisted of the identification of stakeholder characteristics, views and experienced barriers vis-à-vis the uptake and integration of decentralised CHP. Data collection concerned 11 qualitative - that is face to face, in-depth interviews ${ }^{\mathrm{g}}$ with representatives from different stakeholder groups relevant to the uptake of decentralised CHP. A semi-structured questionnaire was used during the interviews. Questions raised addressed the status quo of decentralised CHP uptake in the Ruhr Valley, the future role of this technology in the regional energy system, interaction with district heating, experienced barriers, niche development, policy support strategies and (other) stakeholders' influence on development of this technology in the Ruhr Valley region. Addressing these issues, in particular, the barriers that hinder the uptake and integration of decentralised CHP provide key information necessary for understanding the forms of resistance exercised by the incumbent socio-technical energy regime [1]. 


\section{Systemic analysis of the status quo using the MLP framework}

In this paper, decentralised CHP is treated as a 'niche' (or technology with the potential to become a radical innovation) using the MLP conceptualization, although we argue that this technology has the potential to become a radical innovation and stimulate the (sustainable) transition in the energy system. In order to analyse niche development landscape events, regime factors and niche development will be identified. In common with MLP, the focus of our analysis will be identification of regime forces that tend to block decentralised CHP niche development.

Data used for conducting the analysis included the results from the stakeholder analysis (to a large extent this had identified the barriers) and from an analysis of documents. Next, the data was categorised into three clusters representing the three MLP levels of landscape (macro level), regime (meso level) and niche (micro level). After which, the interlinkages between the three levels were identified.

MLP is used a lot to analyse historical cases [26]. However, in this paper, we use MLP as an analytical tool to identify factors (and their interlinkages) that hinder or support development of a contemporary niche. Hence, MLP is used to assess the status quo of regime forces that influence the niche development of decentralised CHP.

\section{Results}

The results of the Ruhr Valley case study are presented in two parts. First, the results of the stakeholder analysis are presented, in terms of stakeholders' views, positions, interrelations and experienced barriers vis-à-vis the uptake of decentralised CHP. After which, the results of the systemic analysis using MLP are presented.

\section{Results of stakeholders' analysis}

Table 2 presents an overview of the stakeholder characteristics and views regarding the uptake of decentralised CHP. In the table, stakeholders, their positions, interrelations with other stakeholders, opinions towards the uptake of this technology and experienced barriers are presented. Table 2 reveals that consumers - be they private households, the commercial sector or housing associations - are sceptical towards implementation. In the next section, barriers experienced by stakeholders will be discussed in more detail.

\section{Perceived drivers and barriers by stakeholders}

Several drivers and barriers regarding uptake and integration of decentralised CHP can be identified. They can be categorised as: investments, regional characteristics, information deficit and lack of awareness, policy-related barriers, district heating and lack of market services. They will now be discussed in more detail.

\section{Investments}

Decentralised CHP units are still considered relatively expensive (especially upfront investments). Payback periods are considered quite long. Linked to this, another barrier mentioned is the lack of knowledge about business models in relation to contracting or leasing. Return on investment is considered rather low. This is related to legal framework schemes changing frequently and the feed-in tariff for electricity generation, which is becoming unpredictable. Interviewees often draw comparison to the uptake of solar PV in the country. They claim that 'Feed-in tariffs for PV-electricity decreased dramatically in recent years and continue to do so on a monthly basis'. This creates investment uncertainties. Nonetheless, most interviewees believe that current policy and funding conditions are beneficial in respect of the uptake and integration of decentralised CHP.

Among the driving factors mentioned by interviewees increasing energy prices were frequently mentioned, which were linked to the aspiration of establishing 'energy autarkies' and not being dependent anymore on the large-scale energy producers. This idea is currently receiving more attention from different end-user groups. Another driving factor (but linked to the former) that could spur the development of decentralised CHP is the increasing popularity among citizens and local business companies for making local investments. The interviewees observe a trend that 'goes local'. People wish to invest in projects or organisations they can trust and relate to; often in close proximity to their homes. Decentralised CHP plants would offer such investment opportunities for local communities. Citizens' local cooperatives or local business in collaboration with private investors jointly provide the necessary financial means to collectively design, build and operate (renewable) energy production plants, for example wind farms. This example makes clear that our interviewees believe that financial barriers could be potentially be resolved by collective local investments, especially if they are based on popular support by local communities, notably local Bürgerenergiegenossenschaften (authors' translation: citizens' energy cooperatives).

\section{Regional characteristics}

The Ruhr Valley has several specific characteristics that contribute to this area being rather unique. It has a large stock of old buildings, many having a status as a historical monument. Our interviewees view this as a positive reason for installing decentralised CHP units. They state that it is often more economic than retrofitting old buildings (by applying thermal insulation). In the case of conservation of monuments (especially in old fashioned 
Table 2 Stakeholders characteristics and views regarding uptake of decentralised CHP

\begin{tabular}{|c|c|c|c|c|}
\hline Stakeholder & Position and function & Interrelation with other stakeholders & $\begin{array}{l}\text { Opinion towards uptake } \\
\text { of decentralised CHP }\end{array}$ & Experienced barriers \\
\hline $\begin{array}{l}\text { Energy supply companies } \\
\text { (e.g. RWE/E.ON) }\end{array}$ & $\begin{array}{l}\text { Produce and supply energy and operate } \\
\text { some of the local heating grids via } \\
\text { long-term concessions. }\end{array}$ & $\begin{array}{l}\text { Supplies heat and power to end consumer } \\
\text { via DSO. Heavily regulated by government. }\end{array}$ & Negative & $\begin{array}{l}\text { Combining sufficient regional and local } \\
\text { heat demand, failing centralised heating } \\
\text { plants (momentarily absence of heat supply). }\end{array}$ \\
\hline Local governments/cities & $\begin{array}{l}\text { Run local action plans to support uptake } \\
\text { of decentralised CHP. Own public utility } \\
\text { companies that in turn operate local } \\
\text { heating grids. }\end{array}$ & $\begin{array}{l}\text { Serves the common interest. Owns public } \\
\text { utility companies. Relations to other } \\
\text { stakeholders via local decentralised } \\
\text { CHP action plan. }\end{array}$ & Positive/neutral & $\begin{array}{l}\text { Financial deficits, lack of information, lack } \\
\text { of central government (climate) policy to } \\
\text { support decentralised CHP, uncertainty } \\
\text { related to elections, and lack of policy focus. }\end{array}$ \\
\hline Providers of decentralised CHP & $\begin{array}{l}\text { Produce and sell decentralised CHP units } \\
\text { and systems. }\end{array}$ & $\begin{array}{l}\text { Provide CHP unit to end users, housing } \\
\text { corporation or private contractor to } \\
\text { exploit the CHP unit. }\end{array}$ & Positive & $\begin{array}{l}\text { Existing district heating grid, lack of } \\
\text { information, lack of central government } \\
\text { (climate) policy goals to support decentralised } \\
\text { CHP, strong coal and gas lobby in NRW } \\
\text { policymaking venues, elections and lack of } \\
\text { policy focus. }\end{array}$ \\
\hline CHP unit system installers & $\begin{array}{l}\text { Provide installation and maintenance } \\
\text { services that are used by end consumers. }\end{array}$ & $\begin{array}{l}\text { Installs and maintains CHP units as } \\
\text { commissioned by end users, housing } \\
\text { corporation or private contractor to } \\
\text { exploit the CHP unit. }\end{array}$ & $\begin{array}{l}\text { Neutral, albeit hardly aware } \\
\text { of benefits and potential }\end{array}$ & $\begin{array}{l}\text { Status of a historical monument of buildings } \\
\text { and its legal implications, lack of information, } \\
\text { elections and lack of policy focus, lack of } \\
\text { market (support) services, due to small size } \\
\text { little innovation receptive capacity. }\end{array}$ \\
\hline Private contracting parties & $\begin{array}{l}\text { Operate commercial decentralised CHP } \\
\text { units and make contracts with end users. }\end{array}$ & $\begin{array}{l}\text { Contract with end users or housing } \\
\text { corporation. }\end{array}$ & Positive & $\begin{array}{l}\text { Lack of information, many barriers from } \\
\text { other stakeholders indirectly harm } \\
\text { contracting parties. }\end{array}$ \\
\hline Consumers (e.g. households) & $\begin{array}{l}\text { Use of energy produced by decentralised } \\
\text { CHP units (heat and/or electricity). }\end{array}$ & $\begin{array}{l}\text { Contractually related with CHP unit } \\
\text { installer, contracting party, (in some } \\
\text { cases) housing corporations, consultants, } \\
\text { and the DSO. Might be connected to } \\
\text { local government via decentralised CHP } \\
\text { action plan (e.g. recipient of subsidy). }\end{array}$ & $\begin{array}{l}\text { Sceptical, albeit hardly } \\
\text { aware }\end{array}$ & $\begin{array}{l}\text { High upfront investments, lack of financial } \\
\text { governments support, monumental status } \\
\text { of buildings, existing district heating grid, } \\
\text { lack of information, habits of using energy } \\
\text { equipment, transaction costs that go with } \\
\text { CHP unit registration and using subsidies, } \\
\text { elections and lack of policy focus. }\end{array}$ \\
\hline Social housing corporations & $\begin{array}{l}\text { Adopt, own or rent and operate decentralise } \\
d \text { CHP units from which the produced energy } \\
\text { is to be used by tenants of the housing } \\
\text { corporation. }\end{array}$ & $\begin{array}{l}\text { Contractually related with CHP unit } \\
\text { provider, CHP unit installer, contracting } \\
\text { party, DSO and local government, } \\
\text { energy company. }\end{array}$ & Positive & $\begin{array}{l}\text { Lack of information, transaction costs that } \\
\text { go with CHP unit registration and using } \\
\text { subsidies, social housing corporations } \\
\text { legal entitlements and limitations. }\end{array}$ \\
\hline Consultancy/advisory agencies & $\begin{array}{l}\text { Provide advice clients seeking information } \\
\text { on adopting, using and finance of } \\
\text { decentralised CHP. }\end{array}$ & $\begin{array}{l}\text { With commissioner, typically local } \\
\text { governments, housing corporations, } \\
\text { DSOs, some private households and } \\
\text { companies. }\end{array}$ & Positive & $\begin{array}{l}\text { Lack of information, many barriers from } \\
\text { other stakeholders indirectly harm } \\
\text { contracting parties. }\end{array}$ \\
\hline Distribution system operator & & & Depending on ownership & \\
\hline $\begin{array}{l}\text { Owned by municipality } \\
\text { (public utility company; PUC) }\end{array}$ & $\begin{array}{l}\text { Public utility companies operate part of } \\
\text { local heating grids. }\end{array}$ & $\begin{array}{l}\text { Local government, end users, housing } \\
\text { corporations, centralised energy company. } \\
\text { Local government owns PUC. }\end{array}$ & Positive & $\begin{array}{l}\text { Lack of information, concessions preventing } \\
\text { ownership of all local heating grids. }\end{array}$ \\
\hline Owned by RWE/E.ON & $\begin{array}{l}\text { Large energy companies possess } \\
\text { long-term concessions to operate a } \\
\text { part of the heating grids. }\end{array}$ & $\begin{array}{l}\text { Idem. However, energy company } \\
\text { operates grid via concessions, not } \\
\text { the PUC. }\end{array}$ & Negative & $\begin{array}{l}\text { Potential ending of concession contracts. } \\
\text { Loss of local heating grid monopolies. }\end{array}$ \\
\hline
\end{tabular}

commissioned by end users, housing

corporation or private contractor to

Contract with end users or housing

Contractually related with CHP unit installer, contracting party, (in some cases) housing corporations, consultants and the DSO. Might be connected to ocal government via decentralised CH

Contractually related with CHP unit provider, CHP unit installer, contracting local government DSOs, some private households and

dem. However, energy compan operates grid via concessions, not ong-term concessions to operate part of the heating grids. 
mining settlement sites), basic thermal insulation cannot simply be applied since it would damage the fabric of the building and spoil the appearance. Moreover, our interviewees state that there is a good potential to use decentralised CHP units in urban districts that are not connected to district heating grids.

A second condition that could favour the uptake of decentralised CHP technology is the regional highpopulation density and having several big cities sited in close proximity. These conditions allow for a high-heat production potential in the region at close proximity to sites of high heat (and electricity) demand by end users. The important issue here is combining sufficient regional and local heat demand, since CHP plants can only operate economically and efficiently if a significant demand for heat can be ensured and transportation infrastructure of heat is not too long when taking into account potential heat loss.

Third, from an infrastructural point of view, the Ruhr Valley is characterised by an extensive existing district heating grid through which heat is already distributed to many city districts. This grid has however also been listed by the interviewees among the barriers to further uptake and development of decentralised CHP since the current district heating grid supplies sufficient amounts of heat already (from centralised industrial heat production plants). However, the existing grid offers important preconditions for low-carbon heat supply. The interviewees advocate exploring ways to create interconnections between the existing district heating grids and decentralised CHP units. In relation to this claim, one of our interviewees stated: 'It is not the grid that hinders the energy system transition in Germany. It is the energy production utilities that are centralized, large-sized and inflexible plants. Moreover, there is more potential for decentralised units to be integrated (better) into the current district heating system'.

The fourth regional-specific factor, and barrier, is the difficult financial situation in which the majority of the municipalities in the Ruhr Valley now find themselves. They have limited financial means and therefore are not in the position to allocate sufficient budget to promote the uptake and integration of decentralised CHP. Consequently, it is not possible to implement substantial earmarked policy support measures to convince local building owners in making appropriate upfront investments. Next to awareness-raising campaigns and other 'soft policies' local - non-governmental - building owners are left to finance investments in CHP themselves, unless they are able to attract other financial sources for making investments. Another negative consequence from having limited budgetary means is that municipalities have only a limited opportunity to become local 'launching customers'.

\section{Lack of awareness and information deficit}

All interviewees mention the important influence of information provision and awareness raising on the uptake and integration of decentralised CHP in the Ruhr Valley by local stakeholders. They agree, however, that decentralised CHP technology is not familiar among its potential target groups (i.e. private homeowners, housing corporations and companies looking for office space). CHP units are considered as 'not visible' by end users, as they are located in places where people do not notice them, for example in cellars. Interestingly, technological equipment suppliers and service companies (such as those responsible for installation) are often not familiar with the technology. Interviewees claim that it is, to a large extent, this information deficit that is responsible for the lack of decentralised CHP usage in the Ruhr Valley. Several interviewees state that promoting this technology is not easy as the concept is perceived as 'rather difficult to understand'. Moreover, the technology is considered as rather 'complex', notably by those in society who do not engage with energy technology regularly.

Another barrier mentioned by respondents concerns the habits and behaviour of end users. In particular, it is difficult to change habits. However, once end users are familiar with using an energy technology, it is difficult to convince them to switch to using a new (energy) technology (e.g. decentralised CHP) since it requires moving away from a proven technology the user is familiar with. The interviewees suggest that it is possibly easier to convince target groups, when promoting the technology, by mentioning the particular benefits of CHP that would appeal to them. However, this strategy would require data about the target group's heat profiles and that decentralised CHP energy production can be tailored to their specific needs. Unfortunately, there appears to be little information available on individual end-user heat profiles.

Interviewees mentioned pilot projects as a positive driving factor to encourage the uptake and development of decentralised CHP. Pilot projects receive a lot of public attention. It creates awareness and helps familiarise potential adopters of the technology. If the results of a pilot project are positive, then a basis for trust and further experimentation is likely to have been created. Decentralised CHP then becomes known to the potential end users as a more or less 'proven technology'. According to the interviewees, trust in the technology and its installers is of particular importance. It is not unreasonable to assume that one would only invest and adopt, or participate in collectively buying, a decentralised CHP unit if one is convinced that this technology is proven and has long-term added value both financially and environmentally. 


\section{Policy barriers}

Current Federal and State policy frameworks that focus on supporting decentralised CHP technology are viewed by the interviewees as having been well formulated. Essentially, they are considered to create sufficient framework conditions to foster uptake. Several funding instruments are deemed useful and considered as positive driving factors. However, some interviewees believe that the amount of funding offered (for example by feed-in tariffs and subsidies through grants) is not sufficient to promote the uptake. This response seems to be related to the situation in many municipalities in the Ruhr Valley which are suffering from stretched financial budgets (related to the economic crisis). For this reason, municipalities find it difficult to co-fund investments with potential local adopters.

A second barrier mentioned by the interviewees relates to the way in which climate policies have been formulated. Interviewees considered these policies overly ambitious with too long a time horizon as an often cited criticism. As one interviews states: 'Thinking in "big steps" is not appropriate if one strives to really attain climate mitigation and energy transition goals set'. 'Setting policy goals that have to be attained in fifteen, twenty or even forty years fail to create responsibilities as politicians and public officials who are currently in power will - most likely - not be in power anymore once these policy objectives have been or should have been met.' Another interviewee comments underline this point: 'Policymakers hide behind long term goals so that they cannot be held responsible once short term policy goals have not been met'. Hence, in general, climate mitigation policy goals are seen as unrealistic, lacking attention to situational settings, and henceforth fail to address realistic, feasible opportunities to promote the use of decentralised CHP.

Third, complex policy framework conditions are seen as a hindrance factor vis-à-vis the uptake and integration of decentralised CHP. For instance, one interviewee states: 'Once one applies for a financial support scheme one needs to fill in and register a decentralised CHP unit in order to be entitled to receive payments.' This is perceived as a difficult and time-consuming task. Thus, it is considered challenging to comply with all the necessary formalities. This situation applies to both private homeowners and housing corporations. It is with the latter where the greatest potential for adopting decentralised CHP units lies. These corporations are in a position where they can sell both heat and electricity directly to their tenants. However, the contemporary legal framework hinders the housing corporations in becoming energy producers. Opinion is divided between stakeholder groups about whether or not this regulation is the main barrier that prevents housing corporations from installing decentralised CHP units.
A fourth policy-related barrier is the strong coal and gas lobby in the Ruhr area. Policymakers and lobbyists are considered to have very close working relations. The influence that is exerted by the coal and gas lobby on policy making is seen as a strong hindrance to policymaking vis-à-vis supporting the uptake and integration of decentralised power production in general and renewable energy-based technologies in particular.

A fifth policy barrier mentioned is the 2013 national elections. ${ }^{\text {h }}$ Prior to the 2013 elections, interviewees acknowledge it is difficult to foresee which parties will be involved in the new government coalition, and whether the current policies and programs will be maintained. Interviewees claim that it is necessary to wait and see whether developments after the elections will affect current policy framework conditions, especially the long-term goals and the decentralised CHP support policies. As a consequence, investment decisions are postponed until after the elections have taken place and a new government coalition is in power and has published its policy strategies.

\section{District heating}

As mentioned above, the existing district heating grid is seen as a barrier to the uptake and integration of decentralised CHP. Expectations are that several (notably gasfired) power plants will have to shut down in the near future. This already resulted in widespread uncertainties among stakeholders regarding the continuation of heat supply to the district heating grid. One interviewee underlines this by stating that 'A difficult situation needed to be overcome when it turned out that the coal power plant "Datteln 4" with a capacity of 1,050 MW would not start operating in time (if at all). Due to planning mistakes the power plant could not start feeding heat into the district heating grid. As a consequence an alternative solution had to be found'. This event led to strong public protests. Such situations - creating tensions to the current hegemonic energy regime in the region - can consequently spur the development of decentralised energy production (including by small- and medium-sized CHP units) to ensure the continued availability of local heat production. The emphasis on 'decentralised and local' is considered important since it creates independence from the large-scale heat producers from whom security of supply cannot be expected anymore which represents an undermining of trust considered as a factor in the stability of the dominant energy regime.

The role of municipal public utility companies (PUCs) can be seen as a potential influential factor in this respect. In cities that own PUCs, the interviewees observe a large potential to install decentralised CHP units: 'Municipalities could potentially start projects in which public grids connect to decentralised CHP units and their end users.' 
However, ownership of district heating grids by PUCs is not found in all cities in the Ruhr Valley. In some cities, energy companies like RWE and E.ON have district heating grid concessions. This means that municipalities which want to support the integration of decentralised $\mathrm{CHP}$ in district heating systems will be dependent on the willingness of energy companies to see this scale of technology as part of their technology mix. This dependency of the municipalities on a stakeholder which has not shown enthusiasm about decentralised systems is viewed as a substantial barrier by the interviewees.

\section{Lack of market services}

A lack of companies providing services regarding installation and maintenance of decentralised CHP units is perceived as an important barrier by the interviewees. Two reasons were advanced to explain this view. First, installation workers lack proper instructions on how to install and maintain decentralised CHP units. Without these instructions, they simply cannot offer these services to customers, particularly in a manner that is likely to create trust. However, producers of $\mathrm{CHP}$ units and installers do offer courses and training sessions about installation and maintenance of the decentralised units. The difficulty is that such courses need to fit into the day-to-day working of these (typically small-sized) companies. Usually, they have little time or spare staff available (if at all) to participate in these courses, particularly if they are offered during working hours. A related problem in this regard is that this type of small-sized service companies lacks the capacity to specialise in developing services regarding installation and maintenance of decentralised CHP units. This results in a situation where very few (specialised) people need to cover an increasing range of specialised services related to particular technological products.

\section{Results of systemic analysis using MLP}

The stakeholders' analysis presented an overview of barriers that can be seen as regime resistance forces. Major identified barriers relate to (i) lack of financial means for making investments, (ii) lack of awareness regarding the benefits of decentralised CHP to potential users, (iii) the presence of centralised district heating systems, (iv) lack of sufficient policies supporting diffusion of decentralised CHP units, (v) legal stipulations from social housing policies that prevent housing cooperatives from becoming energy producers, (vi) district heating systems owned by public and private owners (via concessions contracts), (vii) lack of skilled service-providing companies and (viii) vested interests by the coal and gas industry. Many of the identified barriers seem interrelated, especially those related to policies promoting decentralised $\mathrm{CHP}$ units and the required investments and training of skilled personnel. In MLP, the identified barriers fall within the following regime forces: energy markets, user preferences, (sectoral) policies and industry. We will now present the results of the MLP analysis, using the MLP categorization of the macro, meso and micro levels.

\section{Macro level: landscape factors}

Although there are many regime barriers (i.e. the problems presented in the previous section), there are also many ('landscape') developments that could potentially offer windows of opportunity to encourage the uptake of decentralised CHP technology. The security of energy supply is no longer taken for granted. Recent problems with heat supply and expectations of rising energy prices can be considered to have played a role in local communities being stimulated to organise their own energy supply with the emphasis on local provision, particularly at the district level. This can be seen as part of a 'decentralisation' trend in Germany [59] in which citizens want to move away from a large centralised organisation of utilities. In that sense, decentralised CHP technology offers a promising alternative, as both heat and power can be produced efficiently at the district level. Moreover, it also allows for the use of renewable energy sources (which appeals to citizens who prefer 'green' energy sources to fossil ones). Connecting to the district heating systems could offer interesting opportunities for upscaling decentralised CHP use (e.g. from the building level to the district level). However, this requires that concession holders of the district heating grid allow for such use and do not only use it but also sell excess heat to industry and the large fossil-fuelled power plants. The ending of district heating systems' exploitation concessions in 2015 offers a window of opportunity for municipalities, local communities and perhaps citizen's energy cooperatives to consider decentralised CHP. Policy frameworks, in particular the Energiewende program, can influence the policy agendas of NRW and the Ruhr Valley municipalities including ownership of the heating grids. Nonetheless, another landscape event, the economic crisis, has had a direct negative financial impact on the capability of governments to allocate budgets for investments in the niche development of decentralised CHP units.

\section{Meso level: regime factors}

Currently, potential users (particularly social housing corporations and private homeowners living in multistorey buildings) are hardly aware of the technology's benefits. When users are aware of the benefits, they appear not to be willing to make the investment required to install decentralised CHP units. This latter situation might be linked to the decision-making practices of building owners. First, private homeowners need collective action in order to decide on investments and plans 
towards installing CHP units. This is time consuming with high-transaction costs. Second, regulations do not allow housing corporations to become energy producers. In addition, decentralised CHP does not seem to match with current user preferences and habits concerning (common) energy consumptive practices. Without social housing policy changing, an important stakeholder is left without institutional allowance to even start using (medium-sized) decentralised CHP units. This situation creates the impression that there is, as yet, little market demand. The installation sector being not willing to invest in specialising in decentralised CHP technology and therefore lacking service provision to accommodate potential users of the technology is also problematic.

The situation with these two stakeholder groups' lack of enthusiasm for decentralised CHP can be linked to the absence of effective support policies, in particular policy instruments to support potential users in making upfront investments. As a consequence, potential users adopt a 'wait and see' strategy and delay making investments until sufficient, trustworthy government programs are in place. As a consequence, current conditions for creating a decentralised CHP (niche) market in the Ruhr Valley are limited. It seems that decentralised CHP still represents a niche in an infant development stage: take off and diffusion into larger market segments is currently not taking place.

\section{Micro level: niche development}

Within the Ruhr Valley, a protected space in which room for experimentation with decentralised CHP is created is the 'Innovation City Ruhr' in the city of Bottrop. The latter was selected by the State of NRW to become a 'climate friendly model city' in the Ruhr Area. The aim is to transform a city district into an energy efficient area, which includes the construction of a decentralised CHP unit based on renewable energy sources, and in so doing provides a best practice example for the larger Ruhr Valley region.

In addition, the policies designed by the nine Ruhr Valley municipalities to support decentralised CHP uptake show a wide scope of actions of how this 'niche' can be further developed. Actions planned by Ruhr area municipalities differ in various ways. Whereas some municipalities only strive to install decentralised CHP in public buildings, others target local stakeholders, like households and commercial firms. Moreover, municipalities deploy different policy actions, such as constructing apartment block-heating installations, integration of decentralised CHP units in urban development planning and establishing contracts with private home owners for the provision of heat. Decentralised CHP is also seen as a means to feed in decentralised-produced heat into the existing district heating grids. Studies regarding the technical and economic potential or feasibility of decentralised
CHP have been prepared in municipalities, and plans for constructing decentralised CHP units are prepared. The ways the city governments address the uptake and integration of decentralised CHP show little coherence: there is little alignment in the formulation of goals and coordination policy actions between Ruhr Valley cities. From a systemic - strategic niche management - perspective, the proposed actions look somewhat promising on the one hand, but rather uncoordinated and little aligned on the other hand. Moreover, there seems not to be sufficient shielding and nurturing of the 'decentralised CHP niche'. The same can be said in respect of the proposed actions to destabilise the incumbent regime structure. Nonetheless, as mentioned before, several landscape events are creating tensions in the regime which could create momentum for further niche development. In the end, however, municipalities cannot bring about systemic change alone. Although cities in the Ruhr Area would like to contribute to climate protection goals with their own utility companies and the possession of the electricity grid, they are depending on other stakeholders, like energy companies and distributed system operators. Many of the district heating concession contracts will end in 2015 which opens up opportunities for regime change. Energy companies are said (according to our interviewees) to use gaps in the energy anti-monopoly regulations to hamper this development. Therefore, a change of regulatory schemes is deemed a necessary requirement to create a level playing field [60].

\section{Discussion}

The Energiewende does not necessarily only need to rely on supporting green electricity production. Actors in urban environments like the Ruhr Valley could also embrace harvesting the potential of energy efficiency goals, in casu adopting decentralised CHP technology. The results, however, show that many barriers have been identified that block the uptake and integration of this technology in practice.

The stakeholder analysis proved useful in giving us more insight into the 'agency' factor of the Ruhr Valley energy system. In line with [38-40], we feel that providing more insight into agency (in our case, by conducting stakeholder analysis prior to using/applying MLP) provides/adds complementary functions in a methodological sense. It contributes to identifying regime barriers and interlevel system dynamics. We leave it to scholars in the field of sustainable transitions to judge whether this can be concerned a methodological 'novel insight'.

Furthermore, we feel that paying attention to specific regional characteristics of the Ruhr Valley is worthwhile as well. Without understanding the industrial character, the availability of district heating infrastructures (and its ownership contracts via concessions), the influence of 
the gas and coal lobby, the large-scale of dwellings owned by social housing corporations and the decentralised governments who can afford little budget to formulate and implement significant niche supporting programs, it is difficult to understand why the Ruhr Valley's energy system is not responding positively to the uptake and integration of decentralised CHP. Hence, in line with [50], we argue that paying special attention to geographically bound comparative (dis-) advantageous circumstances matters in understanding energy system dynamics. Furthermore, we agree with $[48,49]$ that policies also matter and therefore deserve sufficient analytical attention. If policies that intend to support niche developments are non-aligned and are not coordinated with sectoral policies (e.g. social housing policies addressing housing corporations' entitlements in not becoming energy producers), niche development (e.g. uptake of decentralised CHP technology) is not expected to take off [52]. In addition, in the absence of using 'systemic instruments' that exceed local authorities' action plans and jurisdictions, this is not expected to happen either [48]. In conclusion, we agree with Geels [52] that the understanding of power relations at the regime level is critical to the further understanding of greening energy systems. In our opinion, this especially applies to urban, industrial and energy-intensive regions.

Next to addressing the use of MLP and reflecting on the added value of the theoretical contributions to elaborate on MLP, TM and SNM, as mentioned in the academic literature (see the paragraph in the 'Theoretical framework: using the multilevel perspective to analyse regional energy transitions' section), we also want to address the commonalities that our analysis show with results from empirical studies addressing barriers that impede the adoption of (green) energy innovations in city districts. They concern difficulties experienced when trying to have such innovations adopted in existing urban areas, such as the lack of finance, lack of trust and little effective (local) government policies to persuade public (social housing associations) [61,62] and private homeowners [63] to adopt measures to increase the energy efficiency of dwellings. As shown in the Ruhr Valley case study, the lack of market demand and the lack of incentives from the regulatory framework fail to stimulate change in the energy regime. The situation resembles the status quo in (existing) urban contexts in other Western Europe with a lack of diffusion of 'green' energy innovations (see e.g. [64]). Learning from these experiences and taking these lessons into account can be useful for those interested in studying and formulating policies to stimulate adoption of these kinds of innovations (notably addressing energy efficiency), which is now seen as a key challenge in light of the German Energiewende [22].
Generalisation of the results from this study is difficult since we focus on only one case (the Ruhr Valley region). The study, however, can be replicated in other regions. These regions should, however (at least) match some of the main characteristics of the Ruhr Valley region: highly industrialised, energy intensive and urbanised. Studying the results and system innovation indicators of theoretical interest in a set of multiple (comparable) cases would allow for more systematic research and would contribute to the academic literature.

\section{Conclusions}

Energy-intensive regions and energy efficiency in buildings are considered to have taken a backseat in Germany's Energiewende program. Recently, the importance of these issues has received scholarly attention [23]. In this paper, we contribute to this agenda. The main question in this paper is: Which factors block the uptake and integration of decentralised CHP in the German Ruhr area's energy system?

Following a stakeholder analysis, and a systemic analysis using MLP, the results show that the incumbent regime provides substantial barriers that prevent large-scale uptake and integration of decentralised CHP. These barriers relate to lack of financial means for making investments, unawareness and information deficit regarding the benefits of decentralised CHP to potential users, the presence of centralised district heating systems, lack of sufficient policies supporting diffusion of decentralised CHP units, legal stipulations from social housing policies that prevent housing cooperatives from becoming energy producers, district heating systems owned by public and private owners (via concessions contracts), lack of skilled serviceproviding companies and vested interests by the coal and gas industry. Moreover, many of the mentioned factors seem interrelated, especially those linked to policy and finance for upfront investments.

Although the study presented in this paper was conducted in a region with rather unique characters, it would be worthwhile to further the research agenda on the uptake and integration - and more in general: niche development - of decentralised CHP or other decentralised energy production technologies - in regions. Future academic work in this field would particularly be useful if comparative regional studies are conducted. Our paper has also demonstrated the added value of conducting stakeholder analysis as a complementary method to the use of MLP, notably as a way that agency can be explored. Moreover, we argue that conducting a stakeholder analysis prior to studying sustainable transitions in case study research designs using the more commonly used theoretical frameworks and heuristic tools in this disciplinary field (e.g. MLP or SNM) contributes in a methodological sense to the way transition studies address agency. For 
this reason, we encourage future case studies on sustainable transitions to adopt stakeholder analysis methodology.

\section{Endnotes}

${ }^{a}$ [19] EU Tech Energie \& Management (2008) NRWKlima2020 - Beitrag Nordrhein-Westfalens zur Erreichung des nationalen Klimaschutzziels. Aachen

${ }^{b}$ There is one exception: the city of Duisburg. The reason is that the district heating grid already supplies heat to the inhabitants of the municipality. The city already goes beyond the national objective to raise the share of electricity produced in CHP plants to $25 \%$.

${ }^{\mathrm{c}}$ For example, in 2012, the municipality of Oberhausen was the most indebted municipality in Germany [15].

${ }^{\mathrm{d}}$ We would like to stress, however, that in the context of the Ruhr area there is no common conceptualization of 'decentralised CHP'. From our interviews with local practitioners, we conclude that there seem to be multiple understandings of 'decentralised CHP' varying among (types of) stakeholders and contexts.

${ }^{\text {e}}$ For this reason, we decided to include conducting a stakeholders' analysis in our research design. Stakeholder analysis reveals much of existing regime barriers, agency relations, power and politics.

${ }^{f}$ Here we assume a relationship between the spatial type of region and the uptake of CHP. For classifying a region, we assume an ordinal scale which on the extreme can be classified as 'rural/non-industrial' and on the other side as 'urban/high industrial'. Hence, the Ruhr Valley region can be discerned as an 'extreme case' [58] since it is characterised by its very urban and highly industrial nature.

${ }^{\mathrm{g}}$ The interviewees were directors of environmental and climate protection units in city governments, energy consultants at the regional and local level (including a representative from the National CHP Association), managers of energy suppliers, a representative of a public utility company, representatives of an energy agency and a research institute, and a $\mathrm{CHP}$ project manager from city government.

${ }^{\mathrm{h}}$ Data were collected in the weeks prior to the September 2013 elections.

\section{Competing interests}

The authors declare that they have no competing interests.

\section{Authors' contributions}

All authors were involved in drafting the manuscript. All authors read and approved the final manuscript.

\section{Acknowledgements}

The authors would like to thank the Wuppertal Institute for Climate, Environment and Energy and particularly Dr. Johannes Venjakob for his contribution. The institute hosted the main researcher and supported the identification of the stakeholder network and the organisation of interviews. We also like to thank three independent reviewers for assessing the manuscript and providing us with suggestions for improvement.

\section{Author details}

'Department: Nature and Environment, Bonner Str. 100, 42697 Solingen, Germany. ' Department of Governance and Technology for Sustainability (CSTM), Institute for Governance and Innovation Studies (IGS), University of

Twente, Drienerlolaan 5, 7522, NB Enschede, The Netherlands.

Received: 3 December 2013 Accepted: 7 January 2015

Published online: 04 February 2015

\section{References}

1. Jacobssen S, Johnson A (2000) The diffusion of renewable energy technology: an analytical framework and key issues for research. Energy Policy 28:625-640

2. Loorbach D, Verbong G (2012) Governing the Energy Transition, Reality, Illusion or Necessity. Routledge, New York, London

3. Westner G, Madlener R (2011) Development of cogeneration in Germany. A mean-variance portfolio analysis of individual technology's prospects in view of the new regulatory framework. Energy 36:5301-5313

4. Agentur für Erneuerbare Energien (2012) Deutschlands Informationsportal für Erneuerbare Energien. Berlin.

5. Ministerium für Klimaschutz, Umwelt, Landwirtschaft, Natur- und Verbraucherschutz des Landes NRW (2013) Kraft-Wärme-Kopplung. Impulse für Energiewende "Made in NRW". Düsseldorf https://broschueren. nordrheinwestfalendirekt.de/broschuerenservice/energieagentur/kraft-waermekopplung/1550. Accessed on 16 July 2013

6. DSGV\&VKU (2012) Gemeinsam für die kommunale Energiewende. Auf dem Weg in eine klimafreundliche Zukunft, Berlin

7. Presse- und Informationsamt der Bundesregierung (2011) Deutschlands Energiewende. Ein Gemeinschaftswerk für die Zukunft, Berlin

8. Hoppe T, Coenen F (2011) Creating an analytical framework for local sustainability performance: a Dutch case study. Local Environ 16(3):229-250

9. Truffer B, Coenen L (2012) Environmental innovation and sustainability transitions in regional studies. Reg Stud 46(1):1-21

10. EU Tech Energie \& Management (2008) NRW-Klima2020 - Beitrag Nordrhein-Westfalens zur Erreichung des nationalen Klimaschutzziels. Aachen

11. Rip A, Kemp R (1998) Technological change. In: Rayner S, Malone EL (eds) Human Choice and Climate Change. Battelle, Columbus, pp 327-399

12. Geels F (2002) Technological transitions as evolutionary reconfiguration processes: a multi-level perspective and a case study. Res Policy 31:1257-1274

13. Regionalverband Ruhr (2013) Regionalverband Ruhr - Aufgaben und Verbandsgebiet., Essen http://www.metropoleruhr.de/regionalverband-ruhr/ ueber-uns/gebiet-aufgaben.html. Accessed on 28 May 2013

14. Ruhrgebiet Regionalkunde (2013) Die administrative Gliederung des Ruhrgebietes., Essen http://www.ruhrgebiet-regionalkunde.de/ grundlagen_und_anfaenge/kohle/kohle.php? $p=2=0$ Accesed on 28 May $201 \overline{3}$

15. Geographie Infothek (2012) Infoblatt Strukturwandel im Ruhrgebiet. Stuttgart http://www2.klett.de/sixcms/list.php? page $=$ geo infothek\&miniinfothe $=\&$ node $=$ Ruhrgebiet\&article=Infoblatt +Strukturwandel+im+Ruhrgebiet. Accessed on 22 May 2012

16. Beggs C (2011) Energy: Management, Supply and Conservation. Spon Press, London/New York

17. Dena - German Energy Agency (2013) Combined heat and power generation. Berlin http://www.dena.de/en/projects/energy-systems/ combined-heat-and-power-generation.html Accessed on 26 June 2013

18. Dena - German Energy Agency (2013): Kraft-Wärme-Kopplung. Berlin http:// www.effiziente-energiesysteme.de/themen/kraft-waerme-kopplung/herausforderungen.html Accessed on 26 June 2013

19. BMU - Bundesministerium für Umwelt, Naturschutz und Reaktorsicherheit (2009) Langfristszenarien und Strategien für den Ausbau erneuerbarer Energien in Deutschland. Leitszenario, Berlin

20. Eikmeier B, Klobasa M, Toro F, Menzler G (2011) Potenzialerhebung von Kraft-Wärme-Kopplung in Nordrhein-Westfalen, Bremen

21. BET - Büro für Energiewirtschaft und technische Planung GmbH (2013) Perspektiven der Fernwärme im Ruhrgebiet bis 2050. Aachen

22. Gawel E, Lehmann P, Korte K, Strunz S, Bovet J, Köck W, Massier P, Lösche A, Schober D, Ohlhorst D, Tews K, Schreurs M, Reeg M, Wassermann S (2014) The future of the energy transition in Germany. Energy Sustainability Soc 2014(4):15 
23. Kemp R (1994) Technology and the transition to environmental sustainability. Futures 26:1023-1046

24. Geels FW, Schot J (2010) The dynamics of sociotechnical transitions - a sociotechnical perspective. In: Grin J, Rotmans J, Schot J (eds) Transitions to Sustainable Development. Routledge, New York, pp 9-101

25. Geels F (2004) From sectoral systems of innovation to socio-technical systems. Insights about dynamics and change from sociology and institutional theory. Res Policy 33:897-920

26. Markard J, Raven R, Truffer B (2012) Sustainability transitions: an emerging field of research and its prospects. Res Policy 41(6):955-967

27. Smith A, Stirling A, Berkhout F (2005) The governance of sustainable sociotechnical transitions. Res Policy 34:1491-1510

28. Unruh GC (2000) Understanding carbon lock-in. Energy Policy 28:817-830

29. Markard J (2011) Transformation of infrastructures: sector characteristics and implications for fundamental change. J Infrastructure Syst (ASCE) 17:107-117

30. Verbong $G$, Geels $F$ (2007) The ongoing energy transition: lessons from a socio-technical, multi-level analysis of the Dutch electricity system (1960-2004). Energy Policy 35(2):1025-1037

31. Smith A, Raven R (2012) What is protective space? Reconsidering niches in transitions to sustainability. Res Policy 41:1025-1036

32. Kemp R, Schot J, Hoogma R (1998) Regime shifts to sustainability through processes of niche formation: the approach of strategic niche management. Tech Anal Strat Manag 10(2):175-198

33. Raven RPJM (2005) Strategic niche management for biomass: a comparative study on the experimental introduction of bioenergy technologies in the Netherlands and Denmark. PhD thesis, TU/E Eindhoven

34. Rotmans J, Kemp R, van Asselt M, Geels F, Verbong G, Molendijk K (2000) Transities \& transitiemanagement. De casus van een emissiearme energievoorziening, Rotterdam

35. Loorbach DA (2007) Transition management: new mode of governance for sustainable development. PhD thesis. Erasmus University, Rottredam

36. Geels FW, Kemp R (2005) Transitions, transformations and reproduction: dynamics in socio-technical systems. Paper presented at the DRUID Tenth Anniversary Summer Conference, Copenhagen Denmark

37. Shove E, Walker G (2007) CAUTION! Transitions ahead: politics, practice and sustainable transition management. Environ Plann A 39:763-770

38. Van den Bergh JC, Truffer B, Kallis G (2011) Environmental innovation and societal transitions: introduction and overview. Environ Innov Soc Trans $1(1): 1-23$

39. Raven RPJM, Verbong GPJ, Schilpzand WF, Witkamp MJ (2011) Translation mechanisms in socio-technical niches: a case study of Dutch river management. Tech Anal Strat Manag 23:1063-1078

40. Farla J, Markard J, Raven R, Coenen L (2012) Sustainability transitions in the making: a closer look at actors, strategies and resources. Technol Forecast Soc Chang 79(6):991-998

41. Markard J, Truffer B (2008) Actor-oriented analysis of innovation systems: exploring micro-meso level linkages in the case of stationary fuel cells. Tech Anal Strat Manag 20:443-464

42. Grin J (2010) Understanding transitions from a governance perspective. In: Grin J, Rotmans J, Schot J (eds) Transition to Sustainable Development. Routledge, New York/London, pp 221-337

43. Avelino F, Rotmans J (2009) Power in transition: an interdisciplinary framework to study power in relation to structural change. Eur J Soc Theory 12(4):543-569

44. Avelino F (2011) Power in transition: empowering discourses on sustainability transitions. PhD thesis, Erasmus University, Rotterdam

45. Shove E, Walker G (2010) Governing transitions in the sustainability of everyday life. Res Policy 39:471-476

46. Seyfang G, Smith A (2007) Grassroots innovations for sustainable development: towards a new research and policy agenda. Environ Polit 16(4):584-603

47. Arentsen M, Bellekom S (2014) Power to the people: local energy initiatives as seedbeds of innovation? Energy Sustainability Soc 4:2

48. Smits R, Kuhlmann S (2004) The rise of systemic instruments in innovation policy. Int J Foresight Innov Policy 1(1):4-32

49. Weber M, Rohracher H (2012) Legitimizing research, technology and innovation policies for transformative change. Res Policy 41:1037-1047

50. Coenen L, Benneworth P, Truffer B (2012) Towards a spatial perspective on sustainability transitions. Res Policy 41:968-979

51. Geels FW (2011) The multi-level perspective on sustainability transitions: responses to seven criticisms. Environ Innov Soc Trans 1(1):24-40
52. Geels FW (2014) Regime resistance against low-carbon transitions: introducing politics and power into the multi-level perspective. Theory, Culture \& Society doi:10.1177/0263276414531627

53. Bulkeley H, Betsill M (2003) Cities and Climate Change: Urban Sustainability and Global Environmental Governance. Routledge, New York London

54. Bulkeley H (2013) Cities and Climate Change. Routledge, New York London

55. Hoppe T, van den Berg MM, Coenen FHJM (2014) Reflections on the uptake of climate change policies by local governments: facing the challenges of mitigation and adaptation. Energy Sustainability Soc 4:8

56. Hoppe T, van Bueren E (2014) Governing the climate challenge and energy transition in cities. Energy, Sustainability and Society, Thematic Series., http://www.energsustainsoc.com/series/GCCE

57. Gerring J (2007) Case Study Research. Principles and Practices, Cambridge

58. Varvasovszky Z, Brugha R (2000) How to do (or not to do) ... A stakeholder analysis. Health Policy Plan 15:338-345

59. Oteman M, Wiering M, Helderman JK (2014) The institutional space of community initiatives for renewable energy: a comparative case study of the Netherlands, Germany and Denmark. Energy Sustainability Soc 4(1):11

60. Berlo K, Wagner O (2013) Harter Gegenwind bei der Rekommunalisierung. AKP 4:22-23

61. Hoppe T, Bressers H, Lulofs K (2010) Energy Conservation in Dutch Housing Renovation Projects. In: Martens P, Chiang CT (eds) The Social and Behavioural Aspects of Climate Change. Greenleaf, Sheffield, pp 68-95

62. Hoppe T (2012) Adoption of innovative energy systems in social housing: lessons from eight large-scale renovation projects in The Netherlands. Energy Policy 51:791-801

63. Murphy L, Meijer F, Visscher H (2012) A qualitative evaluation of policy instruments used to improve energy performance of existing private dwellings in the Netherlands. Energy Policy 45:459-468

64. Faber A, Hoppe T (2013) Co-constructing a sustainable built environment in the Netherlands-Dynamics and opportunities in an environmental sectoral innovation system. Energy Policy 52:628-638

\section{Submit your manuscript to a SpringerOpen ${ }^{\odot}$ journal and benefit from:}

- Convenient online submission

Rigorous peer review

- Immediate publication on acceptance

- Open access: articles freely available online

- High visibility within the field

- Retaining the copyright to your article

Submit your next manuscript at $>$ springeropen.com 